\title{
PERAN DUKUNGAN MASYARAKAT TERHADAP PENERAPAN PERATURAN DAERAH TENTANG KAWASAN TANPA ROKOK DI RUMAH SAKIT UMUM DAERAH KOTA KENDARI
}

\author{
Andika Mayansara Saboli ${ }^{1}$, La Banudi ${ }^{2}$, Sunarsih ${ }^{3}$ \\ ${ }^{1}$ Mahasiswa Program Studi Magister Kesehatan Masyarakat STIKes Mandala Waluya Kendari, \\ Indonesia: andikamayansara@gmail.com \\ ${ }^{2}$ Jurusan Gizi, Poltekkes Kemenkes Kendari, Indonesia: labanudibanudi@yahoo.com \\ ${ }^{3}$ Program Studi Magister Kesehatan Masyarakat STIKes Mandala Waluya Kendari, Indonesia \\ (Korespondensi e-mail: andikamayansara@gmail.com)
}

\begin{abstract}
ABSTRAK
Tempat yang ditetapkan sebagai Kawasan Dilarang Merokok dilengkapi dengan tanda atau simbol dilarang merokok. Akan tetapi, masih banyak perokok yang merokok di kawasan tanpa rokok tersebut. Penelitian ini bertujuan untuk menganalisis proses Penerapan Peraturan Daerah Tentang Kawasan Tanpa Rokok (KTR) di Rumah Sakit Umum Daerah Kota Kendari. Jenis penelitian ini adalah penelitian kualitatif dengan pendekatan fenomenologis. Informan dalam penelitian ini terdiri dari informan kunci sebanyak 4 orang dan informan biasa sebanyak 3 orang. Hasil penelitian menunjukkan kurangnya komunikasi maupun sosilisasi yang dilakukan oleh pemerintah dan pihak RSUD Kota Kendari terkait perda Kawasan Tanpa Rokok kepada sasaran dalam hal ini masyarakat dan khususnya pengunjung di RSUD Kota Kendari, padahal sosialisasi merupakan hal yang sangat penting di lakukan untuk mengimplementasikan sebuah kebijakan. Diharapkan kepada pemerintah Kota Kendari serta Rumah Sakit Umum Daerah Kota Kendari untuk duduk bersama menjalankan amanat dari aturan yang dibuat yakni melakukan pembentukan satuan tugas khusus pengawasan kawasan tanpa rokok di areal Rumah Sakit Kota Kendari.
\end{abstract}

Kata kunci: Bantuan komunitas, Kawasan bebas kokok, Rumah sakit

\section{Abstract}

Places designated as prohibited smoking areas are provided with no smoking signs or symbols. However, there are still many smokers who smoke in the area without cigarettes. This research aims to analyses the process of implementing the local regulation on the non-smoking area (KTR) at the public hospital in Kendari City district. This type of research is qualitative research with a phenomenological approach. The informant in the study consisted of a key informant of 4 persons and a regular informant of 3 persons. The results of the study showed a lack of communication and socialization conducted by the Government and the parties of the city of Kendari related to District No smoking to the target in this case the community and especially visitors in the Hospital in Kendari City, but Socialization is a very important thing to do to implement a policy. It is expected that the government of Kendari City as well as the public hospital of the city of Kendari to sit together to carry out the order of the rules made that is to form a special task force of supervision of areas in the area of Kendari City Hospital. 


\section{PENDAHULUAN}

World Health Organization (WHO) menjelaskan bahwa rokok menewaskan enam juta orang per tahun di seluruh dunia, termasuk lebih dari 600.000 perokok pasif. Bila tren ini meningkat terus, pada tahun 2030, rokok dapat menyebabkan kematian delapan juta orang per tahun. Sebagian besar negara berkembang memiliki angka yang rendah untuk mereka yang berhenti merokok, walaupun diterapkan berbagai kampanye antirokok di seluruh dunia.

Berdasarkan data terbaru ini, jumlah perokok di seluruh dunia meningkat hampir 250 juta orang antara 1980 hingga 2012. Jumlah perokok di seluruh dunia meningkat menjadi hampir satu miliar orang dan di sejumlah negara termasuk Indonesia dan Rusia lebih dari separuh jumlah penduduk laki-laki mserokok setiap hari (Azkha, 2013; Wati, 2017).

Indonesia merupakan negara ketiga dengan jumlah perokok tertinggi di dunia setelah Cina dan India dengan prevalensi perokok yaitu 36,1\%. Pada tahun 2010, diperkirakan 384.058 orang (237.167 lakilaki dan 146.881 wanita) di Indonesia menderita penyakit terkait konsumsi tembakau. Total kematian akibat konsumsi rokok mencapai 190.260 (100.680 laki-laki dan 50.520 wanita) atau $12.7 \%$ dari total kematian pada tahun 2010. Sedangkan 50\% dari yang terkena penyakit terkait rokok mengalami kematian dini. Penyebab kematian terbanyak adalah penyakit stroke, Jantung Koroner, serta kanker trakhea, bronkhus dan paru (Armayati, 2014; Azkha, 2013).

Proporsi terbanyak perokok aktif setiap hari pada umur 30-34 tahun sebesar 33,4 persen, pada laki-laki lebih banyak dibandingkan perokok perempuan $(47,5 \%$ banding 1,1\%). Berdasarkan jenis pekerjaan, petani/ nelayan/ buruh adalah perokok aktif setiap hari yang mempunyai proporsi terbesar $(44,5 \%)$ dibandingkan kelompok pekerjaan lainnya.
Proporsi perokok setiap hari tampak cenderung menurun pada kuintil indeks kepemilikan yang lebih tinggi. Proporsi penduduk umur $=15$ tahun yang merokok dan mengunyah tembakau cenderung meningkat dalam Riskesdas 2007 (34,2\%), Riskesdas 2010 (34,7\%) dan Riskesdas 2013 (36,3\%). Dibandingkan dengan penelitian Global Adults Tobacco Survey (GATS) pada penduduk kelompok umur $=15$ tahun, proporsi perokok laki-laki 67,0 persen dan pada Riskesdas 2013 sebesar 64,9 persen, sedangkan pada perempuan menurut Global Adults Tobacco Survey (GATS) adalah 2,7 persen (Armayati, 2014; Devhy, 2014; Penelitian \& Kesehatan, 2013)

Dampak asap rokok sudah menjadi isu penting dalam beberapa tahun terakhir. Banyak penelitian mempublikasikan bahaya asap rokok bagi si perokok maupun bagi orang yang berada di sekitarnya. Kebiasaan merokok merupakan perilaku yang sulit untuk diubah karena efek kecanduan yang ditimbulkan dari nikotin, namun disadari untuk dapat mengurangi dampak negatifnya terutama terhadap lingkungan, demi kesehatan masyarakat, harus ada kebijakan efektif yang diambil, salah satunya dengan penerapan kawasan tanpa rokok. Sanksi yang dijatuhkan terhadap pelanggaran kawasan tanpa rokok yaitu sanksi administratif seperti teguran dan denda administrasi (Fatmasari, 2014; Herlambang, 2016).

Sedangkan di Provinsi Sulawesi Tenggara sendiri, proporsi penduduk umur \pm 10 tahun yang memiliki kebiasaan merokok, untuk perokok saat ini yakni perokok setiap hari sebanyak $21,8 \%$ dan perokok kadang-kadang 4,2\%. Sedangkan untuk yang tidak merokok yakni mantan perokok 2,1\% dan bukan perokok 71,1\% (Armayati, 2014; Penelitian \& Kesehatan, 2013).

Peraturan Daerah Kota Kendari Nomor 16 Tahun 2014 tentang Kawasan Tanpa Rokok sudah sesuai dengan amanat Undang-Undang Nomor 36 Tahun 2009 
tentang Kesehatan Pasal 115 Ayat (2), yaitu "Pemerintah Daerah wajib menetapkan kawasan tanpa rokok di wilayahnya" dan Pasal 52 Peraturan Pemerintah Nomor 109 Tahun 2012 tentang Pengamanan Bahan Yang Mengandung Zat Adiktif Berupa Produk Tembakau Bagi Kesehatan, yaitu "Pemerintah Daerah wajib menetapkan Kawasan Tanpa Rokok di wilayahnya dengan Peraturan Daerah". Jika dikaji, pada Pasal 115 Ayat (2) Undang-Undang Nomor 36 Tahun 2009 tentang Kesehatan dan Pasal 52 Peraturan Pemerintah Nomor 109 Tahun 2012, sama-sama menetapkan bahwa pemerintah daerah wajib menetapkan kawasan tanpa rokok di wilayahnya. Oleh sebab itu, kebijakan Walikota Kendari sudah tepat adanya apabila Pemerintah Kota Kendari menetapkan aturan tentang kawasan tanpa rokok. Penelitian ini bertujuan untuk menganalisis proses Penerapan Peraturan Daerah Tentang Kawasan Tanpa Rokok (KTR) di Rumah Sakit Umum Daerah Kota Kendari.

\section{METODE}

Penelitian ini menggunakan metode penelitian kualitatif dengan pendekatan fenomenologis. Penelitian ini telah dilaksanakan di Rumah Sakit Umum Daerah Kota Kendari. Sejak tanggal 19 April sampai dengan 19 Juli 2018. Informan dalam penelitian ini terdiri dari informan kunci sebanyak 4 orang dan informan biasa sebanyak 3 orang. Tehnik penetapan informan menggunakan teknik snowball dan purposive sampling. Untuk mengumpulkan informasi menggunakan teknik observasi, wawancara mendalam dan dokumentasi.

\section{HASIL}

Pengawasan yang dilakukan oleh masyarakat ialah dengan ikut serta dalam memberikan bimbingan dan penyuluhan serta penyebarluasan informasi kepada masyarakat, menegur setiap orang yang melanggar ketentuan kawasan tanpa rokok dan melaporkan kepada pimpinan atau penanggungjawab kawasan tanpa rokok apabila terdapat orang yang terbukti melanggar ketentuan yang telah ditetapkan. Pemerintah Daerah dan RSUD Kota Kendari harus memikirkan dan mengambil langkah konkrit untuk meningkatkan perilaku masyarakat untuk tidak merokok di tempat umum khususnya di Rumah Sakit. Terkait dengan dukungan masyarakat, Adapun bentuk informasi dari informan kunci terhadap bentuk dukungan masyarakat ditunjukkan melalui wawancara mendalam sebagai berikut:

"..Dukungan masyarakat sama aturan
merokok kayak sudah cukup baik.."
(Informan: RN, 54 Tahun, 1 Mei 2018)

“..ini perda kan sejak tahun 2014 kalau ndak salah, jadi dari 2014 itu memang sudah adami perubahan yang dari tadinya bebas merokok di Rumah sakit jadi berkurang.." (Informan: SN, 56 Tahun, 4 Juli 2018)

“..eee kalau mau melihat lebih jauh sebenarnya dukungan masyarakat sudah cukup. Kenapa demikian karena memang berkurangmi masyarakat yang merokok di rumah sakit, terus dibandingkan dengan dulu, dikantin rumah sakit itu dijual rokok tapi sekarang sudah tidakmi. Jadi memang dukungan masyarakat itu sudah cukup baik hanya memang belum maksimal karena masih ada juga didapat pengunjung yang merokok" (Informan: AM, 55 Tahun, 12 Juli 2018)

“..Dukungan sudah cukup baik, hanya memang belum semua masyarakat mendukung .." (Informan: LS, 48 Tahun, 8 Mei 2018)

Berdasarkan dari keterangan informan tersebut, dapat disimpulkan bahwa dukungan masyarakat terhadap aturan kawasan tanpa rokok masih belum maksimal. Meksipun berdasarkan informasi AM bahwa perokok di RSUD kota Kendari telah berkurang dari tahun-tahun sebelumnya, namun tentu saja belum dinilai maksimal karena masih juga terdapat pengunjung yang merokok di lingkungan RSUD Kota Kendari. Sedangkan tanggapan informan biasa mengenai diberlakukannya secara utuh perda no.16 tahun 2014, dijawab beragam oleh informan. Adapun 
hasil wawawancara dijelaskan seperti pada kutipan wawancara berikut:

“...ya setuju..” (Informan: RL, 32 Tahun, 10 Juli 2018)

“..ee iyaa setuju..” (Informan: MK, 30 Tahun, 19 Juli 2018)

Adapun menurut informan RL dan MK bahwa sangat setuju dengan diberlakukannya secara utuh perda no.16 taun 2014 agar bisa menjaga lingkungan dari orang yang merokok, namun hal ini cukup berbeda dari apa yang disampaikan oleh informan SS. Adapun hasil kutipan wawancara dapat dijelaskan sebagai berikut:

“..emm asalkan semuanya mengikuti termaksut juga petugas disini ndk merokok, ma saya ikutmi juga. Tapi jangan sampai kita sudah dilarang-larang ternyata petugasny malah merokok.." (Informan: SS, 29 Tahun, 17 Mei 2018)

Berdasarkan hasil wawancara terhadap informan biasa menunjukkan bahwa adanya perbedaan persepsi dari diberlakukannya secara utuh perda no.16 tahun 2014. Seperti yang disampaikan oleh informan RL dan MK bahwa setuju dengan hal tersebut berbeda dengan SS yang mengungkapkan setuju namun dengan syarat bahwa semua orang mengikuti aturan tersebut bahkan dengan petugas sekalipun.

Untuk melihat dukungan masyarakat, peneliti menanyakan juga kepada informan kunci mengenai tanggapan masyarakat yang ikut serta menjaga lingkungan RSUD dengan melaporkan orang yang merokok. Adapun hasil wawawancara dijelaskan seperti pada kutipan wawancara berikut:

“..setuju sekali.. (Informan: RN, 54 Tahun, 1 Mei 2018)

“..bagus itu kalau ada pengunjung yang mau melaporkan bahwa ada yang lagi merokok. jadi harapannya nanti semua orang ndak adami yang merokok. (Informan: SN, 56 Tahun, 4 Juli 2018)

“..setuju.. memang kan seharusnya masyarakat atau pengunjung rumah sakit ikut serta menjaga lingkungan, jadi kalau ada yang merokok ya dilaporkan. (Informan: AM, 55 Tahun, 12 Juli 2018) “..setuju." (Informan: LS, 48 Tahun, 8 Mei 2018)

Hasil wawancara menunjukkan bahwa keempat informan kunci setuju dengan peran aktif masyarakat yang akan memberikan laporan terhadap pengunjung atau petugas yang merokok. Selain itu, peneliti memberikan pertanyaan mengenai tanggapan informan kunci apabila ada masyarakat yang berjualan rokok di RSUD Kota Kendari. Adapun hasil wawancara dijelaskan seperti pada kutipan wawancara berikut:

“..Tidak boleh,.. namanya kawasan bebas asap rokok, jadi tidak boleh ada yang menjual rokok." (Informan: RN, 54 Tahun, 1 Mei 2018)

“..didalam perda kan sudah diatur dengan sangat jelas bahwa tidak boleh ada yang merokok, juga tidak ada yang menjual rokok.." jadi masyarakat itu ndak boleh memperdagangkan rokok di lingkungan rumah sakit (Informan: SN, 56 Tahun, 4 Juli 2018)

".kami berikan teguran, silahkan ke kantin lihat disitu ada peringatan tidak menjual rokok. jadi ndak boleh ada masyarakat yang menjual rokok...." (Informan: AM, 55 Tahun, 12 Juli 2018)

“..ndak boleh lah.. kan di rumah sakit itu area steril jadi ndak boleh memang orang merokok. kalau ada yang menjual takutnya yang tadinya dia ndak mau merokok tapi karena ada yang menjual jadi dia belimi juga dan merokokmi disitu (Informan: LS, 48 Tahun, 8 Mei 2018)

Hasil wawancara menunjukkan bahwa empat informan setuju tidak boleh ada masyarakat yang berjualan rokok di Rumah Sakit Umum Daerah Kota Kendari. Adapun tanggapan dari informan biasa mengenai peran serta masyarakat untuk menjaga lingkungan RSUD Kota Kendari dari perokok adalah terlihat pada hasil sebagai berikut:

“..ee kalau ada yang saya lihat merokok saya tegur to, suruh matikan.. (Informan: RL, 32 Tahun, 10 Juli 2018)

“..kan saya ini petugas disini jadi kalau ada yang merokok cukup saya suruh dia matikan rokoknya, terus ingatkan bahwa disini 
memang dilarang merokok. (Informan : MK, 30 Tahun, 19 Juli 2018)

“..saya ndak enak mau laporkan orang yang merokok, karena memang sayakan suka merokok.. jadi itu haknya merekaji" (Informan : SS, 29 Tahun, 17 Mei 2018)

Hasil wawancara menunjukkan bahwa 2 informan akan melakukan peneguran langsung kepada orang yang merokok. sedangkan informan SS tidak berani melakukan peneguran atau melaporkan karena informan tersebut juga sering merokok. Berdasarkan hasil wawancara dari keseluruhan aspek dukungan masyarakat bahwa perlu digencarkan dan ditingkatkan lagi sosialisasi mengenai perda aturan rokok ini.

\section{PEMBAHASAN}

Masyarakat mempunyai kesempatan yang seluas-luasnya untuk membantu menciptakan kawasan tanpa rokok. Yang termasuk dalam kategori anggota masyarakat adalah setiap warga kota terlepas dari kedudukan dan jabatannya: dapat perseorangan, kelompok, bahkan anggota SKPD dan Pimpinan/Penanggung Jawab kawasan tanpa rokok di masingmasing sarana kawasan tanpa rokok. karena Keberhasilan peraturan daerah ditandai antara lain dengan semakin banyaknya masyarakat yang patuh dan mampu melakukan kontrol sosial (Azkha, 2013; Devhy, 2014).

Pengawasan yang dilakukan oleh masyarakat ialah dengan ikut serta dalam memberikan bimbingan dan penyuluhan serta penyebarluasan informasi kepada masyarakat, menegur setiap orang yang melanggar ketentuan kawasan tanpa rokok dan melaporkan kepada pimpinan atau penanggungjawab kawasan tanpa rokok apabila terdapat orang yang terbukti melanggar ketentuan yang telah ditetapkan. Pemerintah Daerah dan RSUD Kota Kendari harus memikirkan dan mengambil langkah konkrit untuk meningkatkan perilaku masyarakat untuk tidak merokok di tempat umum khususnya di Rumah Sakit (Armayati, 2014).

Berdasarkan hasil wawancara dari keseluruhan aspek dukungan masyarakat bahwa perlu digencarkan dan ditingkatkan lagi sosialisasi mengenai perda aturan rokok ini. Kesadaran bahaya rokok dan paparan asap rokok merupakan hal yang sangat penting untuk dihindari terutama untuk ibu hamil dan anak-anak (Nugroho, 2015). Namun kesadaran akan bahaya merokok tidak menurunkan angka perokok terutama pada remaja sebagai perokok awal. Komunikasi Informasi dan Edukasi (KIE) sangat penting dilakukan, terutama untuk kalangan muda, tentang bahaya merokok dan bahaya paparan asap rokok. KIE juga harus diberikan pada perokok untuk mendukung adanya perubahan perilaku merokok menjadi tidak merokok (Banudi, 2013).

Komunikasi merupakan suatu penyampaian pesan dari seseorang kepada orang lain untuk mempengaruhi perilaku dan tindakan baik secara langsung maupun tidak langsung. Komunikasi adalah proses pemindahan pengertian dalam bentuk gagasan, informasi dari seseorang ke orang lain (Nasyruddin, 2013). Menurut Edward, persyaratan pertama bagi implementasi kebijakan yang efektif adalah bahwa mereka yang melaksanakan keputusan harus mengetahui apa yang mereka harus lakukan. Setiap keputusan dari suatu kebijakan harus diteruskan kepada personil yang akan menjalankan kebijakan tersebut. Tentunya komunikasi sangat berperan penting dalam mencegah terjadinya berbagai macam interpretasi terhadap setiap kebijakan yang telah dikeluarkan, agar mampu meminimalisir dampak yang mungkin timbul akibat tidak terjalinya komunikasi dengan baik antara pemberi pesan dengan penerima pesan. Menurut Winarno (2012), jika implementasi kebijakan ingin berlangsung efektif, maka perintah pelaksanaan harus konsisten dan jelas (Azkha, 2013; Nugraha \& Yuliawati, 2018). 
Komunikasi yang dilakukan oleh pembuat kebijakan seyogyanya bertujuan untuk mendapatkan dukungan terhadap kelompok sasaran yang akan menjalankan suatu kebijakan, paling tidak harus mencakup berbagai hal penjelasan secara lengkap tentang tujuan kebijakan, manfaat serta keuntungan yang akan dirasakan oleh kelompok sasaran. Peran stakeholder dalam mebangun sebuah komunikasi yang baik sangat berpengaruh dalam efektifnya suatu kebijakan berjalan di lapangan, untuk itu pemimpin dari setiap unit kerja diharapkan mampu melakukan komunikasi baik secara vertikal maupun horizontal untuk memaksimalkan jalannya sebuah kebijakan atau program. Kegiatan penyampaian informasi ini biasa disebut sebagai kegiatan sosialisasi. Sosialisasi dapat di lakukan melalui dua cara yaitu secara langsung dan tidak langsung (Aula, 2010; Azrul, 2006).

Peneliti juga menggali pengetahuan informan terhadap perda Kawasan Tanpa Rokok, adapun hasilnya sebagian besar informan menyatakan bahwa tahu tentang adanya perda Kawasan Tanpa Rokok serta pernah membaca maupun mendengar melaui koran dan dari orang. Akan tetapi isi dari perda tersebut informan tidak mengetahuinya secara mendalam dikarenakan belum pernah membaca draft dari perda tersebut. Namun setelah peneliti menanyakan bahwa daerah apa saja yang wajib menerapkan Kawasan Tanpa Rokok, hampir semua informan mengungkapkan bahwa institusi kesehatan, pendidikan, tempat umum dan bandara adalah tempat yang wajib menerapkan Kawasan tanpa Rokok. Jadi sebenarnya sebagian informan sudah mengetahui bahwa institusi pendidikan adalah salah satu daerah wajib yang menerapkan Kawasan Tanpa Rokok namun belum ada implementasi yang dilakukan sesuai yang tertuang dalam Perda No.16 Tahun 2014 (SOLICHA \& Santosa, 2012).

Penelitian yang juga dilakukan oleh Febriani (2014) di Fakultas Kesehatan Masyarakat Universitas Sumatera Utara dengan judul Hasil penelitian yang dilakukan di Fakultas Kesehatan Masyarakat Universitas Sumatera Utara tersebut ternyata hasilnya ada pengaruh yang signifikan antara dukungan terhadap penerapan Kawasan Tanpa Rokok (KTR) dengan menitik beratkan pada persepsi mahasiswa dan dukungan penerapan Kawasan Tanpa Rokok (KTR) (Febriani, 2014).

Implementasi Kawasan Tanpa Rokok di RSUD Kota Kendari belum berjalan dengan baik dikarenakan kurangnya komunikasi yang terbangun, bahkan informan biasa mengatakan belum pernah melakukan komunikasi dengan pihak RSUD untuk penerapan Kawasan Tanpa Rokok tersebut mereka hanya sebatas tahu saja, tapi tidak memahmi isi perda dan manfaat jika Kawasan Tanpa Rokok diterapkan.

Berdasarkan hasil penelitian sehingga dapat ditarik kesimpulan yaitu masih kurangnya komunikasi maupun sosilisasi yang dilakukan oleh pemerintah dan pihak RSUD Kota Kendari terkait perda Kawasan Tanpa Rokok. Padahal sosialisasi merupakan hal yang sangat penting dilakukan untuk mengimplementasikan sebuah kebijakan karena sosialisasi adalah tahap awal penyebaran informasi mulai dari isi kebijakan, manfaat kebijakan, tujuan kebijakan sasaran dan ruang lingkup kebijakan Kawasan Tanpa Rokok. Dalam penelitian sebelumnya Mumang (2015), menjelaskan bahwa berdasarkan hubungan implementasi kebijakan Kawasan Tanpa Rokok dengan beberapa dimensi variabel komunikasi menunjukkan bahwa keberhasilan implementasi kebijakan Kawasan Tanpa Rokok disebabkan oleh adanya pelaksanaan sosialisasi kebijakan Kawasan Tanpa Rokok. Sosialisasi dapat dilakukan dengan dua cara yaitu, verbal dengan memberikan informasi kepada masyarakat atau pimpinan dari setiap institusi secara langsung dengan melakukan sosialisasi dan nonverbal yaitu, dengan menggunakan media seperti di koran, papan 
pengumuman, media sosial dan sebagainya (Sembiring, 2018).

\section{KESIMPULAN DAN SARAN}

Kurangnya komunikasi maupun sosilisasi yang dilakukan oleh pemerintah dan pihak RSUD Kota Kendari terkait perda Kawasan Tanpa Rokok kepada sasaran dalam hal ini Masyarakat dan khususnya pengunjung di RSUD Kota Kendari, padahal sosialisasi merupakan hal yang sangat penting di lakukan untuk mengimplementasikan sebuah kebijakan.

Adapun yang menjadi saran dalam penelitian ini adalah Perlunya peningkatan sosialisasi baik itu secara langsung tatap muka dan diskusi kepada pasien serta sosialissai dalam bentuk tidak langsung yaitu menambah simbol-simblo pamflet larangan merokok juga dengan mencantumkan sanksi yang akan diterima masyarakat yang melanggar

\section{DAFTAR PUSTAKA}

Armayati, L. (2014). Faktor-Faktor Yang Mempengaruhi Kepatuhan Mahasiswa Dan Karyawan Terhadap Peraturan Kawasan Tanpa Rokok Di Lingkungan Kampus Fakultas Psikologi Universitas Islam Riau. Jurnal Relevansi, Akurasi Dan Tepat Waktu (RAT), 3(3), 543550.

Aula, L. E. (2010). Stop Merokok!(sekarang atau tidak sama sekali). Yogyakarta: Garailmu.

Azkha, N. (2013). Studi efektivitas penerapan kebijakan perda kota tentang kawasan tanpa rokok (ktr) dalam upaya menurunkan perokok aktif di Sumatera Barat tahun 2013.

Azrul, A. (2006). Pengantar Administrasi Kesehatan. Edisi Ketiga, Jakarta: Binarupa Aksara.

Banudi, L. (2013). Gizi Kesehatan Reproduksi. Jakarta: : EGC. Devhy, N. L. P. (2014). Pengaruh Faktor Pengelola terhadap Kepatuhan Pelaksanaan Peraturan Daerah tentang Kawasan tanpa Rokok pada Hotel Berbintang di Kabupaten Badung: Tesis. Program Pascasarjana Universitas Udayana.
Fatmasari, I. (2014). Perilaku Supir Angkutan Pasca Penetapan Perda Kawasan tanpa Rokok di Kota Makassar.

Febriani, T. (2014). Pengaruh Persepsi Mahasiswa Terhadap Kawasan Tanpa Rokok (KTR) dan Dukungan penerapannya di Universitas Sumatera Utara. Karya Tulis Ilmiah stara satu Universitas Sumatera Utara, Sumatera.

Herlambang, S. (2016). Manajemen Pelayanan Kesehatan Rumah Sakit. Yogyakarta: Gosyen Publishing.

Nasyruddin, M. F. (2013). Implementasi Kawasan tanpa Rokok (Ktr) di Sekolah (Studi Kualitatif pada SMP Negeri 21 Semarang). Jurnal Kesehatan Masyarakat Universitas Diponegoro, 2(1).

Nugraha, A. M. A., \& Yuliawati, R. (2018). Hubungan Pengetahuan dan Sikap tentang Kawasan Tanpa Rokok dengan Perilaku Merokok pada Pengunjung RSUD IA Moeis Samarinda.

Nugroho, P. S. (2015). Evaluasi Implementasi Kawasan Tanpa Rokok (KTR) Fakultas Ilmu Kesehatan Universitas Muhammadiyah Surakarta. Universitas Muhammadiyah Surakarta

Penelitian, B., \& Kesehatan, P. (2013). Laporan riskesdas 2013. Jakarta: Badan Penelitian dan Pengembangan Kesehatan.

Sembiring, A. M. (2018). Analisis Peran Pemimpin Agama dalam Implementasi Kawasan Tanpa Rokok (KTR) di Gereja katolik ST. Fransiskus Assisi Pasar VI Padang Bulan Medan.

SOLICHA, R. A., \& Santosa, S. (2012). Tingkat Pengetahuan Dan Sikap Pengunjung Di Lingkungan Rsup Dr. Kariadi Tentang Kawasan Tanpa Rokok. Jurnal Kedokteran Diponegoro, $1(1)$.

Wati, A. R. A. (2017). Penerapan Kawasan Tanpa Rokok berdasarkan Peraturan Daerah Kota Metro Nomor 4 Tahun 2014. JURNAL HIMA HAN, 4(2).

\section{INFORMASI TAMBAHAN}

\section{Lisensi}

Hakcipta (c) 2019 Health Information : Jurnal Penelitian. 
Artikel akses terbuka ini dapat disebarkan seluas-luasnya sesuai aturan Creative Commons Attribution-ShareAlike 4.0 International License dengan catatan tetap menyebutkan penulis dan penerbit sebagaimana mestinya.

Catatan Penerbit: Poltekkes Kemenkes Kendari menyatakan tetap netral sehubungan dengan klaim dari perspektif atau buah pikiran yang diterbitkan dan dari afiliasi institusional manapun. 